\title{
One Hundred Volumes of Neophilologus
}

\author{
Rolf H. Bremmer $\mathrm{Jr}^{1}$
}

Published online: 10 March 2016

(C) Springer Science+Business Media Dordrecht 2016

The attentive reader will have noticed that this year we have entered the onehundred and first year of the existence of our journal and simultaneously have reached the one-hundredth volume. Neophilologus started its existence in Amsterdam in 1916, when in the neighbouring countries the Great War was raging. It would be logical therefore to have started 2016 with the 101th volume, were it not for the German occupation of the Netherlands during World War II and the subsequent liberation by the Allied Forces, that no volume appeared in 1945. It is only proper for a journal that celebrates the appearance of its centenary anniversary to mark this event with appropriate attention. In consultation with the publisher, it was decided to do so with a special book. In order to achieve this publication, the Editorial Board selected form their midst a team, consisting of Frans Ruiter, Usha Wilbers, Thijs Porck and myself, to produce Tracing Paradigms: One Hundred Years of Neophilologus. In addition to an editorial introduction, an anecdotal evaluation of Neophilologus' history and a survey of all the editors up to the present day, the Editorial Board also desired to showcase a profile of the journal by publishing a number of pivotal contributions. To this end, the editors of this celebratory volume asked past and present members of the journal's editorial board to select one or two articles from the past one hundred volumes that in their opinion not only represented their field in a conspicuous way, but also played a role in the subsequent scholarship. Moreover, the contributors were requested to write an essay in which they accounted for their particular choice by critically placing the article in context. Such a set-up, it was deemed, would provide an added value and was to be preferred over a mere anthology of remarkable contributions. It is hoped that these highlights from Neophilologus' rich past, provided with comments from the present, will contribute to the paradigms for its future.

Rolf H. Bremmer Jr

neophilologus@gmail.com

1 Leiden, The Netherlands 
Rolf H. Bremmer Jr, editor-in-chief

\section{Table of Contents}

\section{General}

Rolf H. Bremmer Jr, A Centenary of Neophilologus: Retrospect and Prospect

Sjaak Onderdelinden, "For the time being, things will remain as they are." A Hundred Years of Neophilologus

Thijs Porck, Overview of One Hundred Years of Editors of Neophilologus

\section{Literary Theory}

J. M. Coetzee, Erasmus' Praise of Folly: Rivalry and Madness. Neophilologus 76 (1992), 1-18 (reprint)

Frans Ruiter, In Praise of the Little Phallus: On J. M. Coetzee's Contribution to Neophilologus

\section{French}

Nico van den Boogaard, Le Nouveau Recueil Complet des Fabliaux (NRCF). Neophilologus 61 (1977), 333--345 (reprint)

Roberto Crespo, Le Nouveau Recueil Complet des Fabliaux: à propos d'un article de Nico van den Boogaard dans Neophilologus

Daniel Russell, The Term,emblème'in Sixteenth-century France. Neophilologus 59 (1975), 337-351 (reprint)

Paul J. Smith, L'émergence des études sur l'emblème français: à propos d'un article de Daniel Russell dans Neophilologus

\section{Spanish}

Frederick A. de Armas, Classical Tragedy and Cervantes' La Numancia. Neophilologus 58 (1974), 34-40 (reprint)

Edward H. Friedman, La Numancia within Structural Patterns of Sixteenth-century Spanish Tragedy. Neophilologus 61 (1977), 74-89 (reprint)

Rina Walthaus, La Numancia de Cervantes en Neophilologus. Sobre sendas contribuciones de Armas y de Friedman

José Correa Camiroaga, La estética en Ortega. Neophilologus 66 (1982), 559-568 (reprint)

F. Ebels, Reading in the Frame: Signalling Politics in Nada. Neophilologus 93 (2009), 619-632 (reprint)

Henk Oostendorp, Neophilologus y la literatura española e hispanoamericana posterior a 1800. Sobre sendas contribuciones de Correa Camiroaga y de Ebels 


\section{German}

J. H. Scholte, Versuch eines Bildungsgangs des Simplicissimusdichters. Neophilologus 7 (1922), 190-207 (reprint)

Jef Jacobs, Die Anfänge der wissenschaftlichen Grimmelshausen-Forschung. Zum Beitrag von Jan Hendrik Scholte in Neophilologus

W. G. Sebald, Die Mädchen aus der Feenwelt. Bemerkungen zu Liebe und Prostitition mit Bezügen zu Raimund, Schnitzler und Horvath. Neophilologus 67 (1983), 109-117 (reprint)

Karl Robert Mandelkow, Der deutsche Briefroman. Zum Problem der Polyperspektive im Epischen. Neophilologus 44 (1960), 200-207 (reprint)

Sjaak Onderdelinden, Zwei Aufsätze-zwei Extreme. Zu den Beiträgen von Karl Robert Mandelkow und W. G. Sebald in Neophilologus

\section{English}

J. C. van Meurs, Beowulf and Literary Criticism. Neophilologus 39 (1955), 114-130 (reprint)

Rolf H. Bremmer Jr, Tolkien and Beowulf: On J. C. van Meurs's Contribution to Neophilologus

Nicholas Joost, Ernest Hemingway and The Dial. Neophilologus 52 (1968), 180-190, 304-313 (reprint)

Usha Wilbers, Periodical Studies avant la lettre: On Nicholas Joost's Contribution to Neophilologus 